\title{
Civil Rights Conservation of Female Correctional Facility Inmates in Semarang
}

\author{
Dian Latifiani \\ Faculty of Law, Universitas Negeri Semarang (UNNES), Indonesia \\ Email: dianlatifiani@gmail.com
}

\begin{abstract}
Human as legal subject is a supporter of rights and obligations from living birth to death. Not all legal subjects can perform legal acts, however, only those capable of the law can do so. When it comes to law, nothing can hold back the civil rights. Article 3 of the Civil Code reads that there is no punishment shall result in civil death, or the loss of any citizenship rights. This means that the legal subjects found guilty by a judge for imprisonment, their civil rights still exist. Such as the right to marry, the right to have offspring, property rights (vermogensrechten), material rights (zakelijkerechten), the right over intangible goods (rechten op immateriele goederen). The correctional facility inmates are still having their civil rights safeguarded. This research was intended to identify and analyze how Implication of Article 3 Book of Civil Code for female correctional facility inmates in Semarang. This study employed method of empirical juridical approach which is taking the law into account not only as a normative set of norms or what is the law in the books, but also observing on how the law interacts with the community (law in action). The results of the study indicated that the female correctional facility inmates in Semarang were physically deprived of their independence rights. However, preservation (conservation) of their civil rights still runs according to the implementation of Article 3 of the Civil Code. Conservation of civil rights includes the right to deal with divorce, the right of child care (0-2 years) within the facility, the right to manage the inheritance, the right to take care of the adopted child. The employed legal basis was article 52 PP No. 32 of 1999 on the terms and procedures of the right of the correctional facility inmates.
\end{abstract}

Keywords—civil rights; correctional facility inmates

\section{INTRODUCTION}

Civil law regulates civil rights. In private law every human being has the same right, every individual person is entitled to have the right, but not every human person is authorized to do so. The ratio that every person is entitled to have the right, because in the law sanctions are only applicable and applied to the obligations not on the rights. The willingness to act is essentially an obligation. People who neglect obligations may be subject to sanctions, while those who neglect their rights are all right (Abdulkadir Muhammad, 1993: 38).

The rightful authority is owned by a person from the moment he is born to death. Even the right of authority can be owned by a person from the moment he is in the womb of his mother of origin has been born and his interests willed. This is called the legal fictie. This is stipulated in Article 2 of the Civil Code, which states that a child in the womb of a woman, is considered to have been born, when the child's interests are desirous and dead at birth, it is assumed that she never existed. Then in Article 836 of the Civil Code states that by remembering the provisions of Article 2 of this book, in order to act as an inheritance, a person must have existed at the time of inheritance to fall away. Based on the two articles of the Civil Code, the inheritance will be divided into existing heirs, except in this case the child in the womb of a mother is considered as having been born.

The authority of one's right will end when he is dead. This means that only with death, a person's civil rights will vanish. Even if a person has been punished, his rightful authority is still attached to him. This is affirmed in Article 3 of the Civil Code which states that no punishment also resulted in civil death or loss of any citizenship rights. Observing civil rights / citizenship rights does not depend on the right to state.

Women assisted by the prison Semarang retains civil rights even though they are serving a prison sentence because civil rights are a basic human right inherent in everyone. A civil right is a personal identity that cannot be lost or disappeared. This identity just disappeared or disappeared if the person died. Civil rights differ from public rights. Public rights may disappear or disappear if the state so wishes. The public right exists because it is given by the state, while civil rights are given by nature.

Although the physical prisoners are sentenced to prison but are legally guaranteed the conservation (protected) of their civil rights. This means that civil rights are still obtained even in prisons. Based on the description of the problem discussed how the implementation of Article 3 of the Civil Code of the punishment was not a civil cause death or loss of any rights citizenship to Female prison inmates Semarang? 


\section{RESEARCH METHOD}

The type of research used is qualitative with sociological juridical approach. The focus of this study on prisoners built in prison Women Semarang related to the protection (conservation) of civil rights. The choice of prison Women because, one of the civil rights that is the right to be a mother for her child, the right to give love, care for their children. The data sources used in this study are primary data sources (interviews with prison officers), secondary data sources (documents, books), and tertiary data sources.

\section{RESULT AND DISCUSSION}

Indonesian legislation, which addresses the rights of the assisted citizens, in particular the rights of female assisted citizens. The laws and regulations that will be the authors discussed, among others, are Law Number 12 Year 1995 About Pemasyarakatan, Government Regulation Number 32 Year 1999 About Terms and Procedures Implementation of Rights of Citizens Correctional Penitentiary, Government Regulation Number 28 Year 2006 About Amendment To Government Regulation Number 32 of 1999 concerning Terms and Procedures for the Implementation of the Right of Citizens of Correctional Prisoners, and Government Regulation Number 99 of 2012 on the Second Amendment to Government Regulation Number 32 Year 1999 concerning the Terms and Procedures for the Implementation of Right of Residents of Correctional Prison.

The guidance in prisons of Class IIA Women Semarang includes:

Functions and duties of fostering of Penitentiary Prisoners (WBP) are implemented in an integrated manner with the aim that after they have finished their crime, their guidance and guidance can be good citizens.

Li Li's Room Coaching in Class IIA Women Semarang (https://lpwanitasemarang.wordpress.com/lingkuppembinaan)

1. Coaching Personality , including:

a. Development of Religious Awareness.

1) Islam; Tausiah / Lecture, Yasin \& Tahlil together, Pesantren Jumat, Counseling Religion of Islam, Learning to Read AlQur'an, Ramadan Pesantren, SETF / Ruqyah, Commemoration of Islamic Religion Day etc

2) Christianity \& Catholicism; Regular service, Bible study, Holy

Communion, Baptist, Song Leader

Training, Counseling, Celebration of

Christian \& Catholic Day

3) Buddhist / Hindu Religion; Guidance Buddhism / Hinduism, Counseling great Memorial Day Buddhism / Hinduism

b. National and State Awareness

That is coaching which aims to foster a sense of discipline, love the homeland, nation and state. This is done in several ways including including the WBP on the implementation of the flag ceremony there is a national big day, singing a national anthem on a particular occasion, applying WBP apples every morning and so on.

c. Coaching intellectual ability (intelligence).

1) Program Kejar Paket A, B dan C is implemented in cooperation with SKB Semarang City

2) Through courses and trainings, among others: Hair \& Face Makeup, Anggrek Culture, Culinary, Screen Printing etc.

3) Through counseling counseling include counseling of character, psychology, religion, law etc.

4) Opens the widest opportunity to obtain information through TV, as well as newspapers, magazines and radio.

5) Opening Reading Gardens and Libraries

6) Coaching in order to improve accountability and discipline.

d. Fostering legal awareness.

e. Coaching physical/physical; Volley Ball, Table

Tennis, Yoga, Gymnastics, Badminton, etc.

f. Art; Karawitan, Band, Modern Dance, Dance (Java, Papua etc.), Qasidah, Theater etc.

g. Coaching Integration; Parole, Free Leave (CMB), Conditional Leave (CB), Assimilation

2. Coaching Independence; Tailoring, Payet, Embroid ery, Cooking, Mushroom Cultivation, Raising i right, $\mathrm{Cr}$ ochand etc. The citizens assisted by the Women's Correctional Class of IIA in 2016 based on the history of education are mostly highly educated. More detailed data are shown in the following table:

Table 1. Classification of Citizenship Education Year

\begin{tabular}{|l|c|}
\hline \multicolumn{2}{|c|}{ Education 2016} \\
\hline $\begin{array}{l}\text { Not Passed Elementary } \\
\text { School }\end{array}$ & 14 people \\
\hline SD & 40 people \\
\hline SMP & 29 people \\
\hline SMA & 293 people \\
\hline
\end{tabular}

Source: Bimaswat 2016

Classification of Citizen Guidance seen from the type of Crime is divided into 3 namely the criminal acts of corruption, Criminal and Drugs as in the following table: Table 2 . Type of Crime and the origin of the Bought Residents in 2016

\begin{tabular}{|c|c|c|c|c|}
\hline \multirow[b]{2}{*}{ No } & \multirow[b]{2}{*}{$\begin{array}{l}\text { Type of } \\
\text { Crime }\end{array}$} & \multicolumn{2}{|c|}{ Origin } & \multirow[b]{2}{*}{ amount } \\
\hline & & $\begin{array}{l}\text { Central } \\
\text { Java }\end{array}$ & $\begin{array}{c}\text { Outside of } \\
\text { Central } \\
\text { Java }\end{array}$ & \\
\hline 1 & Corruption & 31 & 2 & 33 \\
\hline 2 & Criminal & 38 & 22 & 60 \\
\hline 3 & Drugs & 57 & 226 & 283 \\
\hline & Total & & & 376 \\
\hline
\end{tabular}


The basic principle of building inmates, there are four elements as a pillar in conducting coaching, including themselves, family, community, and prison officers. Related to the four elements, the guidance of prisoners must know the purpose of coaching, development coaching, difficulties encountered and various problem solving, which is a unity that cannot be separated from each other (Petrus Soerjowinoto. 2012: 56).

Article 3 of the Civil Code states that no punishment shall result in civil death or loss of any citizenship rights. It means that civil rights are always attached to a person, although in this case legal subjects have legal problems, such as committing a criminal act, then what is lost is its independence not civil rights.

Based on provisions for residents the guard who wants to take care of the civil rights is given the opportunity to leave the prison permit in accordance with the applicable rules, in Government Regulation No. 32 of 1999 Article 52 also provides an opportunity related to taking care of correspondence with family and friends are allowed. Civil rights of a citizen guaranteed in Law Number 12 Year 1995 regarding Corrections, Dinin ti with their Article 5 paragraph g which describes the loss of independence is one - the only one suffering, this is explained further with the explanation "loss of independence is the only one suffering " is a Prisoner of Correctional Institution must be in LAPAS for a period of time certain, so that the state has a full chance to improve it. While in LAPAS, Penuduk Correctional Residents still get their other rights like human beings, in other words the right of his / her rights remain protected as rights get health care, eat, drink, clothes, bed, exercise skills, sports, or recreation.

Protection of civil rights that have been guaranteed to have implications on the implementation of reality in the field. $\mathrm{P}$ enelitian using purposive sampling technique who once exercised civil rights. A da two married mothers and children. While interviewing 37year-old Nining, who was involved in a Narcotics crime in Solo when he was executed, he was sentenced to a 5-year, 4-month trial in a prison classroom A Semarang. Nining's mother has 3 sons who are quite big, Ms. Nining gets good treatment to exercise her civil rights, in the case of taking care of housing compensation due to expelation, from then on during prison he still able to take care related to the administration of the letter which must be prepared to get compensation (Interview result October 10, 2016) .

Inmates were both successful we interviewed is Dikriyah aged 34, caught by authorities in criminal offenses of trafficking in Batang, when execution ng sung Berla he was sentenced to 3 years and 3 months. Have 2 children who have grown teenagers. According to him he gets a fair treatment while exercising his rights. At that time, he took care of the inherent property that is the right of his children. Due to the divorce that occurred with her husband. In terms of taking care of the correspondence he can still get permission from the Head of Prisons (Interview Result October 10, 2016).

Based on the results of research on female prisoners are not found any deviation of civil rights suffered by prisoners in accordance with the rules in force. The civic rights of the two prisoners went well, for example in the case of taking care of the indemnity for eviction of the house experienced by Nining's mother obtaining permission from the Prison Head. In terms of inheritance, as undertaken by Mrs. Dikriyah. They have acquired the rights of civilization in other matters such as taking care of divorce. Arrangements are made in religious courts with the opportunity to follow the course of the trial process.But Mrs. Dzikriyah and Mrs. Nining did not take the opportunity with the consideration of having intend to divorce because there is no match with her partner.

Based on interviews conducted with Ibu Kurniawati Dewi (Kasubsie Bimkemwat/Community Guidance and Care) stated that as a legal subject having rights and obligations in law (human and legal entity). Although the condition of the prisoner being punished by the judge is proven, it still does not make the loss of its provision as well as his civil rights (Interview Result, October 8, 2018)

\begin{tabular}{|c|l|l|l|c|c|c|}
\hline \multirow{2}{*}{ No } & \multirow{2}{*}{ Type of Right of Civility } & \multicolumn{4}{|c|}{ Year } \\
\cline { 3 - 7 } & & $\mathbf{2 0 1 2}$ & $\mathbf{2 0 1 3}$ & $\mathbf{2 0 1 4}$ & $\mathbf{2 0 1 5}$ & $\mathbf{2 0 1 6}$ \\
\hline 1 & Takes care of inheritance & 1 person & 1 person & 1 person & 1 person & 1 person \\
\hline 2 & A child's dys- tition(Prisoner's Son adopted by others) & - & - & - & 1 person & 1 person \\
\hline 3 & Parenting ( 0-2 years) & - & - & - & 1 person & 1 person \\
\hline 4 & Divorce & - & - & - & - & 3 people \\
\hline 5 & Marriage & - & - & - & - & - \\
\hline
\end{tabular}

Source: Processed from interview with Kurniawati Dewi (Kasubsie Bimkemwat/Community Guidance and Care) on 11 November 2016

Basically the pattern of coaching women with other prisons there is no difference. One of the factors is the establishment of women's prisons is a security consideration. However, there are specific things that must be considered are things related to personal rights concerning themselves such as menstruation, childbirth, drugs when sick, of course, cost. The financing comes from the inmates by setting aside the money they have. In the Semarang Women's Quarters, based on our research, it is more advisable to collect the money they have in the cooperative than to bring them into a prison cell.

This proves that prisons in this case as a coaching institution for prisoners still provide widespread space and opportunities for prisoners who will take care of their civil rights in accordance with the applicable rules mechanism. As stated in Law Number 12 Year 1995 regarding Corrections that the Penitentiary System aims to return the Prisoners of Correctional Facilities as good citizens and to 
protect the community against the possibility of repeated criminal acts by the assisted citizens and is an application and an integral part of the values that contained in Pancasila. The penitentiary system focuses on care, coaching, education, and guidance to assisted citizens aimed at restoring the unity of the interrelationships individual assisted citizens and community.

The implementation of correctional guidance is based on the principles of the penal system to nurture, nurture, educate and guide the targeted citizens in order to become citizens good and useful. Residents assisted in the penitentiary system have the right to obtain coaching spiritually and temporally their right to observe their worship, to engage with outsiders family or other parties, obtain information, either through print or electronic media, obtain a proper education and so on. In article 52 of Government Regulation No. 32 Year 1999 explains about civil rights.

(1) Other civil rights in this Government Regulation shall include:

a. correspondence with family and friends;

b. permission to exit LAPAS in extraordinary matters.

(2) Prisoners and Prisoners can send outgoing mail of LAPAS and accept a letter from outside the LAPAS as referred to in paragraph (1) letter a.

(3) Prisoners and protégés can be given permission to exit such as referred to in paragraph (1) letter $b$.

(4) The permission to exit the BAPAS as referred to in paragraph (3) is granted by the Head of LAPAS.

"correspondence" in this regulation includes telegram, parcel and goods prints and any writings as well as other items that can be used for preach anything. The letter may not be directly sent or received by the prisoners or the Correctional Student but must pass through inspection or consideration of the officer security or designated. Furthermore, on this article, extraordinary matters referred to "extraordinary things" is earnest extraordinary in nature include:

a. death / severity of father, mother, child, grandchild, husband, wife, brother or sister;

b. be the guardian of his son's marriage;

c. dividing inheritance.

In extraordinary condition by showing supporting evidence, then the prisoner was given permission to exit the LAPAS for 24 hours and not stay.

Artificial citizens are given the opportunity to get paid leave to visit the family from the prison head. What is meant by "leave" is the form of guidance of the Prisoner leaving the MAP for a while, if it has fulfilled the conditions specified in the prevailing laws and regulations. "Leave to visit family" is a form of coaching Prisoners and Correctional Students in the form of the opportunity to gather with family at the residence of his family. "Family" means: wife or husband, biological or adoptive child, biological or adoptive parent or stepbrother or sister-in-law, sibling or adoptive or step-brother or sister-in-law, other close family to second degree, horizontally or vertically.

\section{CONCLUSION}

The Female Prisoners of Semarang are physically deprived of their liberty. However, the maintenance (conservation) of civil rights still runs according to the implementation of Article 3 of the Civil Code. Conservation of civil rights includes the right to organize divorce, the right of child care (0-2 years) in prisons, the right to take care of inheritance, the right to take care of the adopted child. Basic law that is used is article 52 PP. 32 of 1999 on conditions and procedures for the right of the prisoners of the penitentiary. Procedures in taking care of civil rights (Permission to exit prison on condition of extraordinary condition) that is ; a) The prisoner citizen appeals for the right of civil rights to the Head of the Prison with accompanying supporting evidence, b) Head of LAPAS checks and considers and resolves, c) The head of the prison grants approval to the Beneficiary to exit at maximum $1 \times 24$ hours with full escort.

\section{REFERENCES}

[1] Abdulkadir Muhammad, Hukum Perdata Indonesia, Citra Aditya Bhakti, 1993

[2] https://lpwanitasemarang.wordpress.com/lingkuppembinaan/

[3] Undang-Undang Nomor 12 Tahun 1995 Tentang Pemasyarakatan

[4] Peraturan Pemerintah Nomor 32 Tahun 1999 Tentang Syarat dan Tata Cara Pelaksanaan Hak Warga Binaan Pemasyarakatan

[5] Peraturan Pemerintah Nomor 28 Tahun 2006 Tentang Perubahan Atas Peraturan Pemerintah Nomor 32 Tahun 1999 Tentang Syarat dan Tata Cara Pelaksanaan Hak Warga Binaan Pemasyarakatan

[6] Peraturan Pemerintah Nomor 99 Tahun 2012 Tentang Perubahan Kedua Atas Peraturan Pemerintah Nomor 32 Tahun 1999 Tentang Syarat dan Tata Cara Pelaksanaan Hak Warga Binaan Pemasyarakatan. 